\title{
ZOOTAXA
}

2857

\section{Revision of Metaconchoecia (Ostracoda: Halocyprididae) and the designation of two new tribes Conchoeciini and Metaconchoeciini}

\author{
VLADIMIR G. CHAVTUR ${ }^{1} \&$ MARTIN V. ANGEL $^{2}$ \\ ${ }^{1}$ Laboratory of Planktonology of A.V.Zhyrmunsky's Institute of Marine Biology, Far East Branch, Russian Academy of Science, \\ Vladivostok 690041,Russia.E-mail:vchavtur@gmail.com \\ ${ }^{2}$ National Oceanography Centre, Empress Dock, Southampton SO14 3ZH UK. E-mail: mva@noc.soton.ac.uk
}

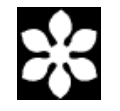

Magnolia Press

Auckland, New Zealand 
Vladimir G. Chavtur \& Martin V. Angel

Revision of Metaconchoecia (Ostracoda: Halocyprididae) and the designation of two new tribes Conchoeciini and Metaconchoeciini

(Zootaxa 2857)

84 pp.; $30 \mathrm{~cm}$.

29 April 2011

ISBN 978-1-86977-713-5 (paperback)

ISBN 978-1-86977-714-2 (Online edition)

\section{FIRST PUBLISHED IN 2011 BY}

Magnolia Press

P.O. Box 41-383

Auckland 1346

New Zealand

e-mail: zootaxa@mapress.com

http://www.mapress.com/zootaxa/

(C) 2011 Magnolia Press

All rights reserved.

No part of this publication may be reproduced, stored, transmitted or disseminated, in any form, or by any means, without prior written permission from the publisher, to whom all requests to reproduce copyright material should be directed in writing.

This authorization does not extend to any other kind of copying, by any means, in any form, and for any purpose other than private research use.

ISSN 1175-5326 (Print edition)

ISSN 1175-5334 (Online edition) 


\title{
Table of contents
}

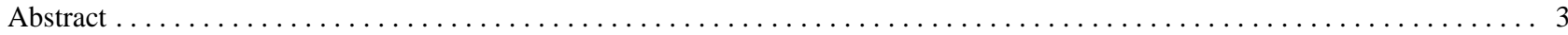

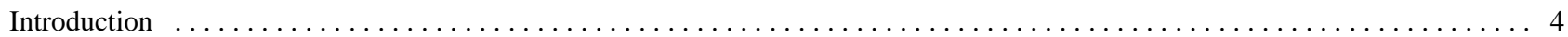

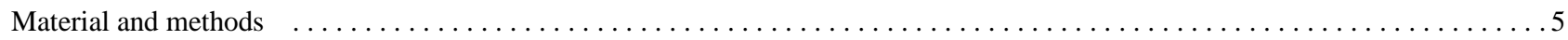

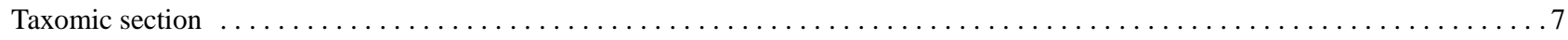

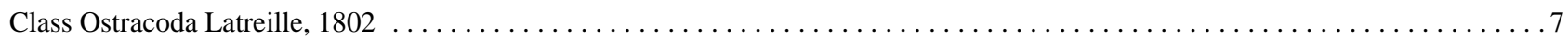

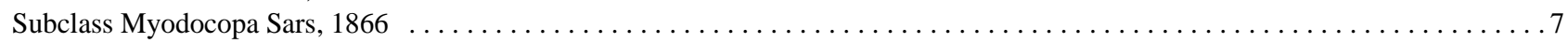

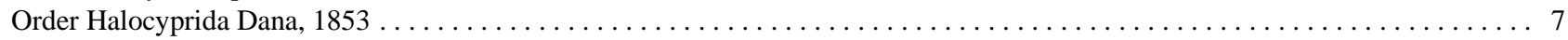

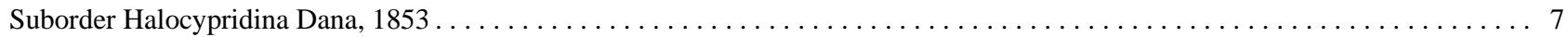

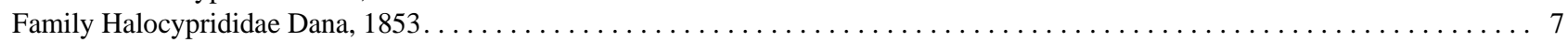

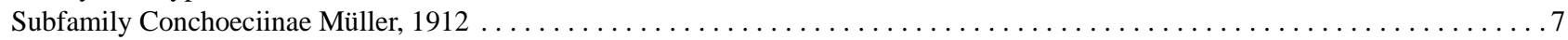

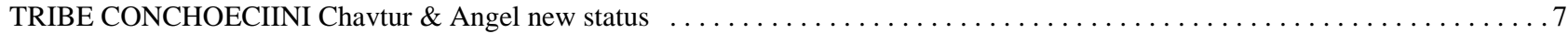

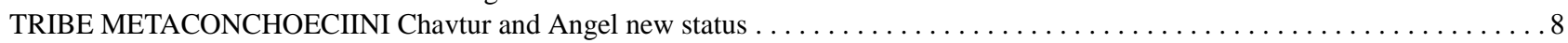

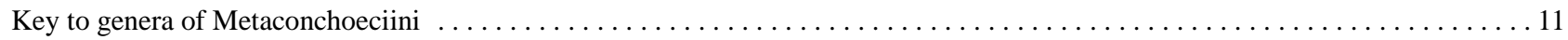

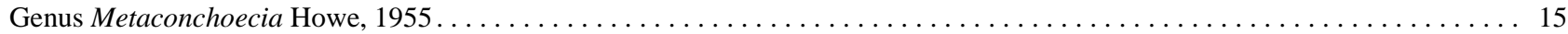

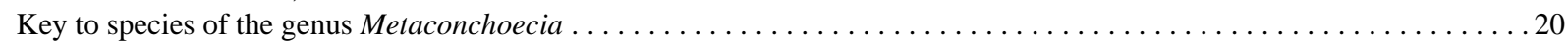

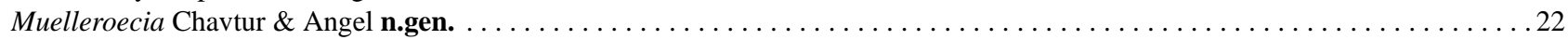

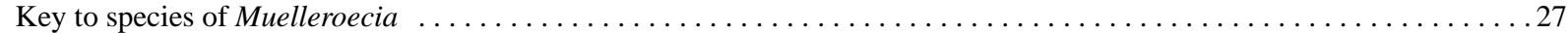

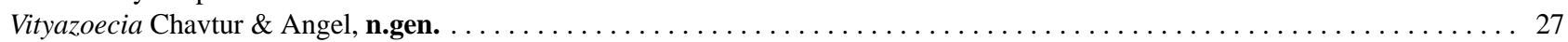

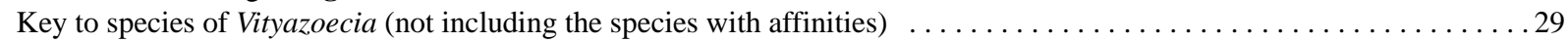

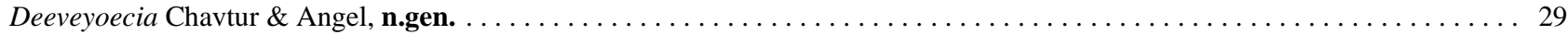

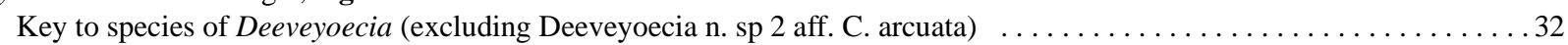

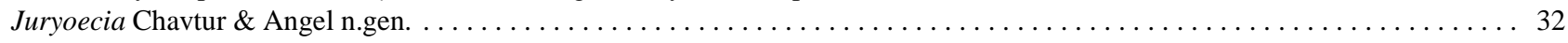

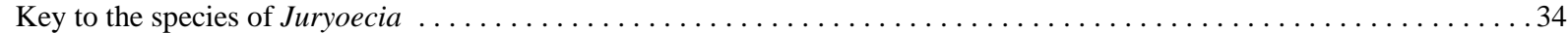

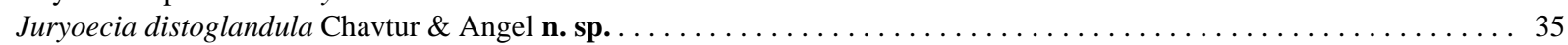

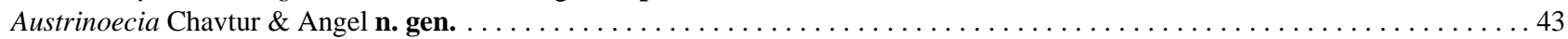

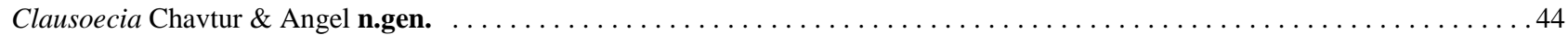

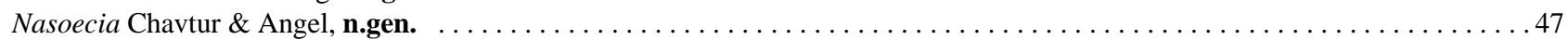

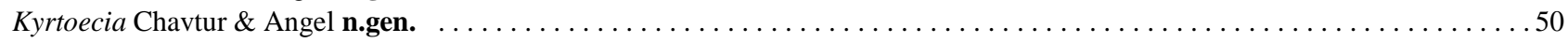

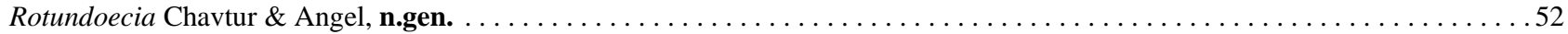

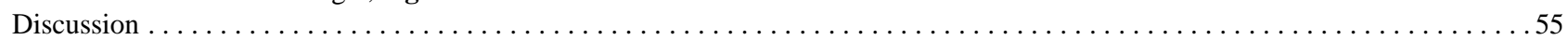

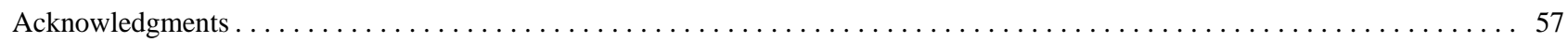

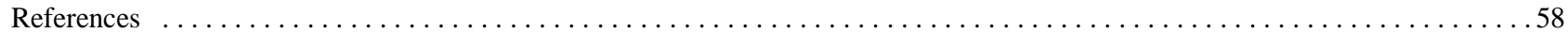

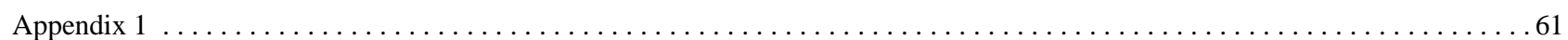

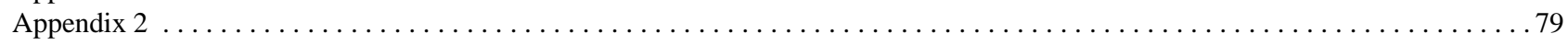

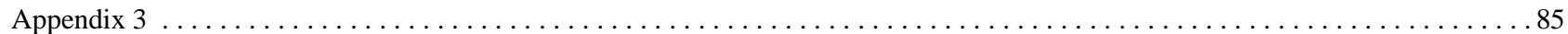

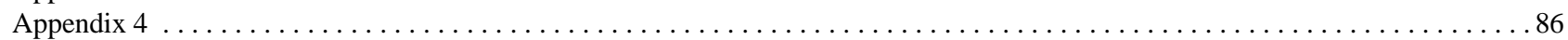

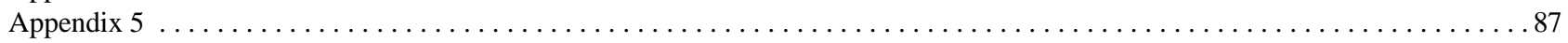

\begin{abstract}
A new tribe of pelagic Ostracoda (Halocyprididae), the Metaconchoeciini, is established to encompass all the species formerly classified in the genus Metaconchoecia. All the remaining genera in the subfamily Conchoecinae are, therefore, assigned to another new tribe, the Conchoeciini. The original genus Metaconchoecia is subdivided into ten genera. Metaconchoecia is retained and nine new genera established namely: Austrinoecia, Clausoecia, Deeveyoecia, Juryoecia, Kyrtoecia, Muelleroecia, Nasoecia, Rotundoecia and Vityazoecia. Keys to these new genera and their component species are provided. Tables summarize the characters that most readily distinguish between the most closely related taxa. Appendices summarize the taxonomic characters and detailed size data for the majority of species that occur in the Atlantic and the North Pacific. A new species, Vityazoecia distoglandula, is described, which is designated as the type species of its genus.
\end{abstract}

Key words: morphology, taxonomy, zooplankton, oceanic, Atlantic, North Pacific, Vityazoecia distoglandula n. sp. 